\title{
Reclassification of Gluconacetobacter hansenii strains and proposals of Gluconacetobacter saccharivorans sp. nov. and Gluconacetobacter nataicola sp. nov.
}

\author{
Puspita Lisdiyanti, $†$ Richard R. Navarro, Tai Uchimura \\ and Kazuo Komagata
}

Correspondence

Tai Uchimura

tai@nodai.ac.jp
Department of Applied Biology and Chemistry, Faculty of Applied Bioscience, Tokyo University of Agriculture, Sakuragaoka 1-1-1, Setagaya-ku, Tokyo 156-8502, Japan

Ten strains previously assigned to Acetobacter hansenii (= Gluconacetobacter hansenii), Acetobacter pasteurianus LMG 1584 and eight reference strains of the genus Gluconacetobacter were reclassified by $16 \mathrm{~S}$ rRNA gene sequencing, DNA-DNA similarity, DNA base composition and phenotypic characteristics. The $A$. hansenii strains and $A$. pasteurianus LMG 1584 were included in the cluster of acetic acid bacteria (family Acetobacteraceae) by $16 \mathrm{~S}$ rRNA gene sequences. Further, they were separated into seven distinct groups by DNA-DNA similarity. DNA-DNA similarity group I was identified as G. hansenii. DNA-DNA similarity group II was retained as Gluconacetobacter sp., because DNA-DNA similarity between the strain and Gluconacetobacter entanii LTH $4560^{\top}$ could not be determined. This was due to a lack of availability of the type strain from any source. DNA-DNA similarity group III was regarded as a novel species, for which the name Gluconacetobacter saccharivorans sp. nov. (type strain, LMG $1582^{\top}=\mathrm{NRIC} 0614^{\top}$ ) is proposed. DNA-DNA similarity group IV included the type strains of Gluconacetobacter oboediens and Gluconacetobacter intermedius, and three A. hansenii strains. This group was identified as $G$. oboediens because high values of DNA-DNA similarity were obtained between the type strains and G. oboediens has priority over $G$. intermedius. DNA-DNA similarity group V was identified as Gluconacetobacter europaeus. DNA-DNA similarity group VI was regarded as a novel species, for which the name Gluconacetobacter nataicola sp. nov. (type strain, LMG $1536^{\top}=$ NRIC $0616^{\top}$ ) is proposed. DNA-DNA similarity group VII was reclassified as Gluconacetobacter xylinus. The description of $G$. hansenii is emended.
The species Acetobacter hansenii was established by numerical analysis of phenotypic features and protein gel electropherograms (Gosselé et al., 1983b). The species was then transferred to the genus Gluconacetobacter on the basis of ubiquinone systems and partial 16S rRNA gene sequences (Yamada et al., 1997, 1998). However, protein gel electropherograms and some phenotypic features (Gosselé et al., 1983b) had already suggested the heterogeneity of the strains comprising A. hansenii. Further, four distinct DNA-DNA homology groups were recognized in Gluconacetobacter

tPresent address: Research Center for Biotechnology, Indonesian Institute of Sciences, Jalan Rya Bogor km 46, Cibinong 16911, Indonesia.

The GenBank/EMBL/DDBJ accession numbers for the 16S rRNA gene sequences determined in this study of strains NBRC 14816, NBRC 14817, NBRC 14820'르. LMG 1688, NBRC 14822, LMG 1689, LMG 1582 ${ }^{\top}$, LMG 1584, NBRC 3261, LMG $1536^{\top}$, NBRC 14815 JCM 9730 ${ }^{\top}, \mathrm{JCM} 7644^{\top}, \mathrm{JCM} 10150$, DSM $6160^{\top}$ and DSM $11826^{\top}$ are $A B 166734-A B 166744$ and $A B 205217-A B 205221$, respectively. hansenii strains (Navarro et al., 1999). Homology group I was identified as $G$. hansenii and the other three groups remained unnamed. Two G. hansenii strains (LMG $1517=$ NBRC 14822 and LMG 1689) were identified as Gluconacetobacter intermedius by partial 16S rRNA gene sequences and HaeIII and HpaII restriction profiles of the PCR-amplified 16S-23S rDNA spacer region (Trček \& Teuber, 2002). G. hansenii LMG $1582^{\mathrm{T}}$ was suggested to be a novel species on the basis of the above-mentioned sequences and profiles (Tř̌ek, 2002).

The aim of the present study was to reclassify ten strains previously identified as A. hansenii (=G. hansenii) (Gosselé et al., 1983b; Navarro et al., 1999) and Acetobacter pasteurianus LMG 1584 (=A. pasteurianus subsp. pasteurianus LMD 39.5) (Table 1). A. pasteurianus LMG 1584 was used throughout the present study because the strain was transferred to the genus Gluconacetobacter (Lisdiyanti et al., 2000). Gluconacetobacter entanii LTH $4560^{\mathrm{T}}$ was not used in the present study because its transportation made it very 
Table 1. List of strains studied

\begin{tabular}{|c|c|c|c|}
\hline Strain no. & Received as & History & Source \\
\hline $\mathrm{NBRC}^{\star} 14820^{\mathrm{T}}$ & G. hansenii & $\begin{array}{l}<\text { Shizuoka Univ. (Y. Yamada) }<\text { NCIB } 8746^{\mathrm{T}} \\
<\text { J. L. Shimwell }<\text { M. Schramm }\end{array}$ & Local vinegar, Jerusalem, Israel \\
\hline NBRC 14817 & G. hansenii & $\begin{array}{l}<\text { Shizuoka Univ. (Y. Yamada) }<\text { NCIB } 8246 \\
<\text { J. Senez < M. Aschner }\end{array}$ & Local vinegar, Jerusalem, Israel \\
\hline NBRC 14816 & $\begin{array}{l}\text { G. hansenii homology } \\
\text { group unknown }\end{array}$ & $\begin{array}{l}<\text { Shizuoka Univ. (Y. Yamada) < NCIB } 8747 \\
<\text { J. L. Shimwell }<\text { M. Schramm }\end{array}$ & Local vinegar, Jerusalem, Israel \\
\hline NBRC 14815 & $\begin{array}{l}\text { G. hansenii homology } \\
\text { group IV } \dagger\end{array}$ & $\begin{array}{l}<\text { Shizuoka Univ. (Y. Yamada) } \\
<\text { NCIB } 8752<\text { T. K. Walker }\end{array}$ & Malt vinegar brewery acetifiers \\
\hline LMG 1582 & A. hansenii & $\begin{array}{l}<\text { LMD ('A. mesoxydans subsp. saccharovorans') } \\
<\text { J. Frateur ('A. mesoxydans var. sucrasiferum') } \\
<\text { Institut für die Essigindustrie Berlin } \\
\text { ('Bacterium dihydroxyacetonicum') }\end{array}$ & Beet juice \\
\hline LMG 1584 & A. pasteurianus & $\begin{array}{l}<\text { LMD ('A. mesoxydans subsp. saccharovorans') } \\
<\text { K. Bernhauer ('A. dioxyacetonicum var. pectinatum') }\end{array}$ & \\
\hline NBRC 14822 & $\begin{array}{l}\text { G. hansenii homology } \\
\text { group II } \dagger\end{array}$ & $\begin{array}{l}<\text { Shizuoka Univ. (Y. Yamada) < NCIB } 4940 \\
<\text { NCTC } 4940<\text { A. C. Thaysen }\end{array}$ & \\
\hline LMG 1688 & A. hansenii & $<\mathrm{LMD}$ & \\
\hline LMG 1689 & A. hansenii & $\begin{array}{l}<\text { LMD ('A. xylinum var. xylinoides') } \\
<\text { W. Henneberg ('Bacterium xylinoides') }\end{array}$ & \\
\hline NBRC 3261 & $\begin{array}{l}\text { G. hansenii homology } \\
\text { group II } \dagger\end{array}$ & $<$ NBRC $($ K. Kondo, 42) & $\begin{array}{l}\text { Myrica rubra (fruit), Nishinomiya, } \\
\text { Hyogo, Japan }\end{array}$ \\
\hline LMG 1536 & A. hansenii & < E. Magno ('A. xylinum’) & Nata, Manila, Philippines \\
\hline DSM $6160^{\mathrm{T}}$ & G. europaeus & $<$ M. Sievers & Vinegar, Germany \\
\hline $\mathrm{JK} 2$ & G. europaeus & $<$ J. Trček & Vinegar \\
\hline DSM $11804^{\mathrm{T}}$ & G. intermedius & $<$ C. Boesch, ETH; TF2 & $\begin{array}{l}\text { Tea fungus beverage (kombucha), } \\
\text { Switzerland }\end{array}$ \\
\hline DSM $11826^{\mathrm{T}}$ & G. oboediens & < S. J. Sokollek \& W. P. Hammes & $\begin{array}{l}\text { Industrial red wine vinegar } \\
\text { fermentation, Germany }\end{array}$ \\
\hline JCM $7644^{\mathrm{T}}$ & G. xylinus & $<$ NCIB $11664^{\mathrm{T}}<$ NCTC $4112<$ G. Bertrand & \\
\hline $\mathrm{JCM} 9730^{\mathrm{T}}$ & $\begin{array}{l}\text { G. xylinus subsp. } \\
\text { sucrofermentans }\end{array}$ & $<$ T. Tsuchida BPR $2001^{\mathrm{T}}$ & Cherry, Japan \\
\hline JCM 10150 & $\begin{array}{l}\text { 'G. xylinus subsp. } \\
\text { nonacetoxidans' }\end{array}$ & $<$ T. Tsuchida BPR 2002 & Grape, Japan \\
\hline NBRC $12388^{\mathrm{T}}$ & G. liquefaciens & $\begin{array}{l}<\text { Shizuoka Univ. }<\text { IAM } 1834^{\mathrm{T}} \\
<\text { IAM }(\text { T. Asai, G-1) }\end{array}$ & $\begin{array}{l}\text { Diospyros sp. (dried persimmon), } \\
\text { Japan }\end{array}$ \\
\hline NBRC $14818^{\mathrm{T}}$ & A. aceti & $\begin{array}{l}<\text { Shizuoka Univ. (Y. Yamada) }<\text { NCIB } 8621^{\mathrm{T}} \\
<\text { W. Verhoeven }<\text { J. Frateur }\end{array}$ & Alcohol turned to vinegar \\
\hline
\end{tabular}

*IFO cultures were transferred to NBRC (NITE Biological Resource Center, National Institute of Technology and Evaluation, Kisarazu-shi, Chiba 292-0818, Japan) with the same accession numbers.

$\dagger$ Homology groups by Navarro et al. (1999).

difficult to obtain (C. Hertel, Institut für Lebensmitteltechnologie, Universität Hohenheim, Stuttgart, Germany, personal communication) and it was not available from any culture collections.

Sequencing of the 16S rRNA gene and the construction of a phylogenetic tree were carried out as reported previously (Lisdiyanti et al., 2000; Yamada et al., 2000). The 16S rRNA gene was amplified by PCR with two primers: 20F (5'-GATTTTGATCCTGGCTCAG-3', positions 9-27) and 1500R (5'-GTTACCTTGTTACGACTT-3', positions
1509-1429). The numbering of positions was based on the Escherichia coli numbering system (GenBank accession no. V00348; Brosius et al., 1981). The purified PCR products were sequenced directly by using an ABI PRISM BigDye Terminator Cycle Sequencing Ready Reaction kit and an ABI PRISM 310 genetic analyser. The following six primers were used: 20F, 1500R, 520F (5'-CAGCAGCCGCGGTAATAC-3', positions 519-536), 520R (5'GTATTACCGCGGCTGCTG-3', positions 536-519), 920F (5'-AAACTAAATGAATTGACGG-3', positions 907-926) and 920R (5'-CCGTCAATTCATTTGAGTTT-3', positions 


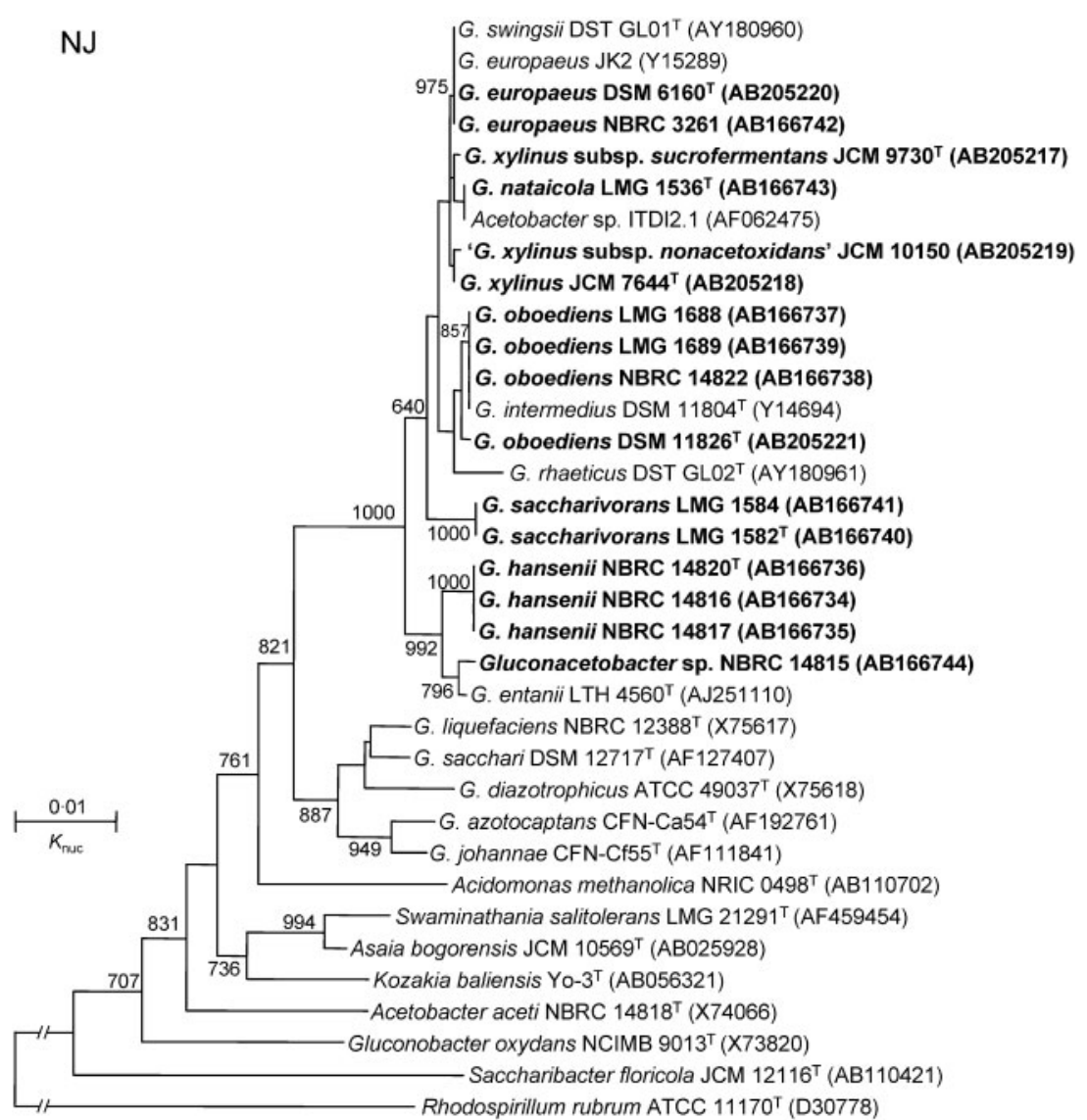

Fig. 1. Phylogenic relationships of acetic acid bacteria deduced from 16S rRNA gene sequence clustering by neighbour joining. Numbers indicate the bootstrap value derived from 1000 replications. Sequences determined in this study are shown in bold. Rhodospirillum rubrum ATCC $11170^{\top}$ (GenBank accession no. D30778) was used as an outgroup. Bar, 0.01 substitutions per nucleotide position.
926-907). Multiple alignments were performed in the program CLUSTAL_W (Thompson et al., 1997). Distance matrices for the aligned sequences were calculated by the two-parameter method ( $\left.K_{\text {nuc }}\right)$ (Kimura, 1980). Neighbourjoining (NJ) (Saitou \& Nei, 1987), maximum likelihood (ML) (Felsenstein, 1981) and maximum parsimony (MP) (Felsenstein, 1983) were employed for constructing phylogenetic trees. The robustness of individual branches of the NJ tree was estimated by bootstrapping with 1000 replicates (Felsenstein, 1985). Alignment gaps and unidentified base positions were not taken into account for the calculations. The 16S rRNA gene sequences of ten $G$. hansenii strains, $A$. pasteurianus LMG 1584, Gluconacetobacter oboediens DSM $11826^{\mathrm{T}}$, Gluconacetobacter europaeus DSM $6160^{\mathrm{T}}$, Gluconacetobacter xylinus JCM $7644^{\mathrm{T}}$, G. xylinus subsp. sucrofermentans JCM $9730^{\mathrm{T}}$ (Toyosaki et al., 1995) and ' $G$. xylinus subsp. nonacetoxidans' JCM 10150 (Kojima et al., 1998) were determined in the present study. InforBIO, an eworkbench for the databasing, classification and identification of microbes, was used for the analysis of the phylogenetic trees (Sugawara et al., 2003; www.wdcm.org). Available 16S rRNA gene sequences were obtained from GenBank/EMBL/DDBJ. Species, type strains, strains and GenBank accession numbers are presented in Figs 1-3.

Phylogenetic trees of the strains studied and reference strains of the genus Gluconacetobacter were rather similar to each other when produced by NJ and MP (Figs 1, 2). A phylogenetic tree of the strains produced by ML was a little different from those produced by NJ and MP (Fig. 3). However, all of the strains were included in the cluster of the genus Gluconacetobacter, in a broad cluster of the acetic acid bacteria (family Acetobacteraceae). Further, the species of the genus Gluconacetobacter seemed likely to be separated into two subclusters. One consisted of Gluconacetobacter swingsii, G. europaeus, Gluconacetobacter nataicola, $G$. xylinus, G. oboediens, G. intermedius, Gluconacetobacter rhaeticus, Gluconacetobacter saccharivorans, G. hansenii and $G$. entanii, and $16 \mathrm{~S}$ rRNA gene sequence similarity was $98 \cdot 1-99 \cdot 9 \%$ between the type strains of the above species. The other cluster consisted of Gluconacetobacter liquefaciens, Gluconacetobacter sacchari, Gluconacetobacter diazotrophicus, Gluconacetobacter azotocaptans and Gluconacetobacter johannae, and the 16S rRNA gene sequence similarity was 98.4-99.16\% between the type strains of these species. Further, the $16 \mathrm{~S}$ rRNA gene sequence similarity between the two subclusters was $95 \cdot 7-97 \cdot 6 \%$.

DNA was extracted and purified as reported by Saito \& Miura (1963). The medium was the same as that described previously (Navarro \& Komagata, 1999). A filter-sterilized cellulase (cellulase of Trichoderma viride; Wako) solution was added to the liquid medium at a final concentration of $0.025 \%$ for the extraction of DNA from cellulose-producing strains. The cellulase was added before cultivation. This enabled the extraction of DNA from the strains because 


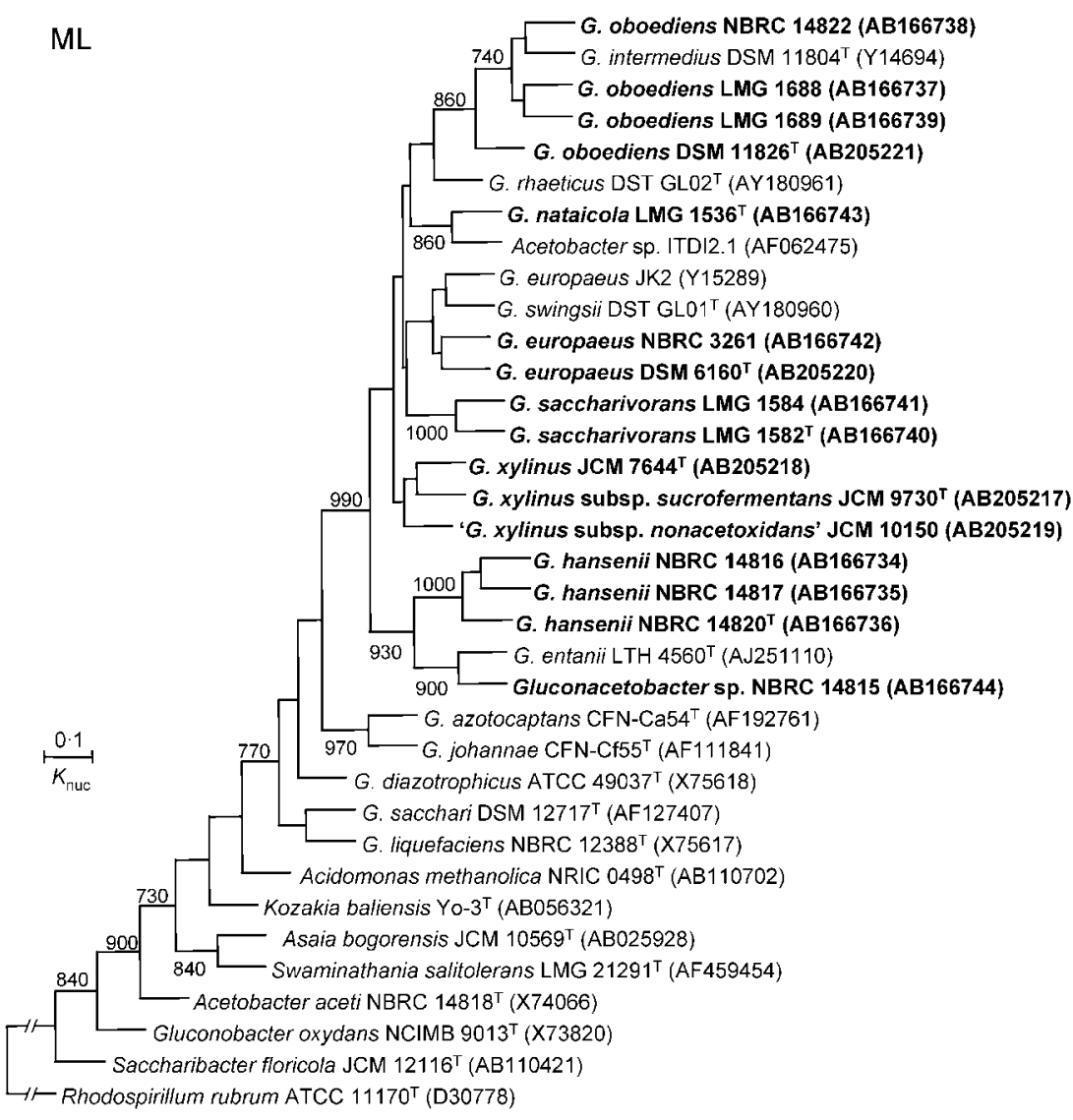

Fig. 2. Phylogenic relationships of acetic acid bacteria deduced from 16S rRNA gene sequence clustering by maximum likelihood. Numbers indicate the bootstrap value derived from 1000 replications. Sequences determined in this study are shown in bold. Rhodospirillum rubrum ATCC $11170^{\top}$ (GenBank accession no. D30778) was used as an outgroup. Bar, $0 \cdot 1$ substitutions per nucleotide position. cellulose production was prevented by cellulase. DNA-DNA hybridization was performed as described by Ezaki et al. (1989) at $50{ }^{\circ} \mathrm{C}$, a stringent hybridization temperature. $\mathrm{G}+\mathrm{C}$ contents were determined as described by Tamaoka \& Komagata (1984). DNA base compositions of the strains studied fell into a range of $57-63 \mathrm{~mol} \% \mathrm{G}+\mathrm{C}$ (Table 2).

According to the phylogenetic relationships of 16S rRNA gene sequences, DNA-DNA similarity was determined between the strains of G. europaeus, G. xylinus, G. nataicola, G. oboediens, G. intermedius, G. saccharivorans, G. hansenii and Gluconobacter sp. NBRC 14815, and seven DNA-DNA similarity groups were delineated in the present study (Table 2). DNA-DNA similarity group I contained $G$. hansenii NBRC $14820^{\mathrm{T}}$, NBRC 14816 and NBRC 14817, and was identified as $G$. hansenii because these strains showed high levels of DNA-DNA similarity (80-100\%) to the type strain and one another. These strains showed 99.9-100\% 16S rRNA gene sequence similarity to one another. DNADNA similarity group II contained a single strain, NBRC 14815. This strain showed 99.9\% 16S rRNA gene sequence similarity to G. entanii LTH $4560^{\mathrm{T}}$. However, NBRC 14815 should be retained as Gluconacetobacter sp. because the type strain of G. entanii was not available from any source and the DNA-DNA similarity could not be determined. This case raises a problem about the identification of such strains in the future. DNA-DNA similarity group III included LMG $1582^{\mathrm{T}}$ and LMG 1584. These strains were identical to each other and separate from other groups based on DNA-DNA similarity. Therefore, the strains were regarded as a novel species, for which the name Gluconacetobacter saccharivorans sp. nov. is proposed. LMG $1582^{\mathrm{T}}$ was previously suggested to belong to a novel species based on a partial $16 \mathrm{~S}$ rRNA gene sequence and HaeIII and HpaII restriction profiles of the PCR-amplified 16S-23S rRNA gene spacer region (Trček, 2002). This author's suggestion was confirmed in the present study. DNA-DNA similarity group IV contained G. oboediens DSM $11826^{\mathrm{T}}$, G. hansenii NBRC 14822, LMG 1688 and LMG 1689 and G. intermedius DSM $11804^{\mathrm{T}}$. Their $16 \mathrm{~S}$ rRNA gene sequence similarity was 99.9-100\% to one another. High levels of DNA-DNA similarity and the similarity of $16 \mathrm{~S}$ rRNA gene sequence revealed a synonymous relationship between $G$. oboediens and G. intermedius. G. oboediens has priority over $G$. intermedius (Boesch et al., 1998a, b; Sokollek et al., 1998) and $G$. intermedius is a later heterotypic synonym of $G$. oboediens. As a result, this group was identified as $G$. oboediens. LMG 1517 ( = NBRC 14822) and LMG 1689 were identified previously as $G$. intermedius by partial $16 \mathrm{~S}$ rRNA gene sequences and HaeIII and HpaII restriction profiles of the PCR-amplified 16S-23S rDNA spacer region (Tř̌ek \& Teuber, 2002). The present study confirmed their identification. DNA-DNA similarity group $\mathrm{V}$ included $G$. europaeus DSM $6160^{\mathrm{T}}$, G. europaeus JK2 and NBRC 3261 and was identified as G. europaeus because these strains showed high levels of DNA-DNA similarity (70-100\%) to 


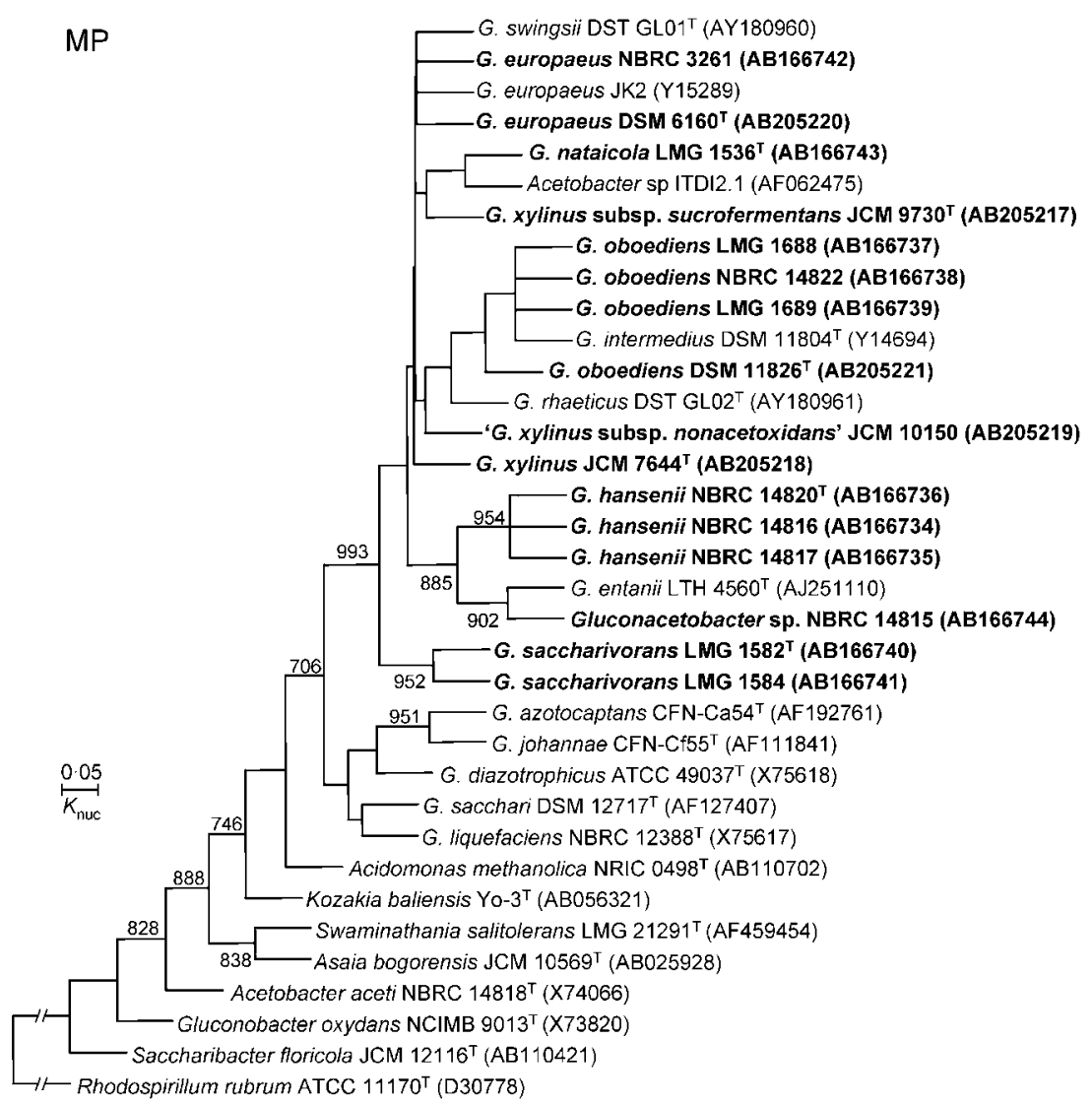

Fig. 3. Phylogenic relationships of acetic acid bacteria deduced from 16S rRNA gene sequence clustering by maximum parsimony. Numbers indicate the bootstrap value derived from 1000 replications. Sequences determined in this study are shown in bold. Rhodospirillum rubrum ATCC $11170^{\top}$ (GenBank accession no. D30778) was used as an outgroup. Bar, 0.05 substitutions per nucleotide position. the type strain and one another. A high value of DNA-DNA similarity (98\%) was reported between G. europaeus DSM $6160^{\mathrm{T}}$ and strain JK2 (Trček et al., 2000). It is interesting that NBRC 3261 was maintained without notation of requirement of acetic acid in the culture collection. DNA-DNA similarity group VI contained only LMG $1536^{\mathrm{T}}$. This strain was located together with Acetobacter sp. ITDI 2.1, which was isolated from nata de coco (Bernardo et al., 1998), and close to G. europaeus and G. xylinus strains (Figs 1,2) with 99.7-99.9\% 16S rRNA gene sequence similarity. LMG $1536^{\mathrm{T}}$ was differentiated from G. europaeus and G. xylinus by DNA-DNA similarity. Therefore, this strain was regarded as a novel species, for which the name Gluconacetobacter nataicola sp. nov. is proposed, according to its isolation source. DNA-DNA similarity group VII included G. xylinus JCM $7644^{\mathrm{T}}$, G. xylinus subsp. sucrofermentans JCM $9730^{\mathrm{T}}$ and ' $G$. xylinus subsp. nonacetoxidans' JCM 10150, and was identified as G. xylinus because these strains showed high levels of DNA-DNA similarity (67-100\%) to the type strain and one another. This study confirmed high levels of DNADNA similarity of G. xylinus strains and G. xylinus subsp. sucrofermentans as reported by Tanaka et al. (2000). Recently, G. swingsii and G. rhaeticus were described and these species were separated from the type strains of the $G$. xylinus branch (Dellaglio et al., 2005).

The present study emphasized that when a bacterial species was established without DNA-DNA similarity data between the strains used, such a bacterial species should be reexamined for the similarity between the strains comprising the species for the stability of nomenclature. DNA-DNA similarity is still a reliable criterion for distinguishing bacterial species when clear-cut, differential phenotypic characteristics have not yet been found among the species (Cleenwerck et al., 2002; Katsura et al., 2002; Navarro et al., 1999; Lisdiyanti et al., 2000).

Isoprenoid quinones were extracted as described by Yamada et al. (1969) and determined by HPLC (Komagata \& Suzuki, 1987). Three strains (NBRC 14816, LMG $1536^{\mathrm{T}}$ and LMG 1584 ) and two reference strains (DSM $11804^{\mathrm{T}}$ and JK2) had ubiquinones, with Q-10 accounting for $>90 \%$ and Q-9 for $<10 \%$ of the total ubiquinones. Thus, all Gluconacetobacter strains used in the present study had Q-10 as the major quinone, in agreement with data reported previously (Navarro et al., 1999).

Phenotypic characterization of the strains studied was mostly carried out as described previously (Lisdiyanti et al., 2000). Production of acid from ethanol and oxidation of ethanol were examined by clearing around colonies (Frateur, 1950; Swings et al., 1992). Growth in the presence of $0.35 \%$ acetic acid was examined by using AG medium. This medium was used for the separation of the species in the genera Asaia and Saccharibacter from those of the genera Acetobacter, Gluconobacter, Acidomonas, Gluconacetobacter, Kozakia and Swaminathania (Jojima et al., 2004; Katsura 
Table 2. DNA base compositions and levels of DNA-DNA similarity of strains studied

Strains: 1, G. hansenii NBRC $14820^{\mathrm{T}}$; 2, Gluconacetobacter sp. NBRC 14815; 3, G. saccharivorans LMG 1582 ${ }^{\mathrm{T}}$; 4, G. saccharivorans LMG 1584; 5, G. oboediens DSM 11826 ${ }^{\mathrm{T}}$; 6, G. oboediens NBRC 14822; 7, G. oboediens LMG 1688; 8, G. intermedius DSM 11804 ${ }^{\mathrm{T}}$; 9 , G. europaeus DSM $6160^{\mathrm{T}}$; 10, G. europaeus JK2; 11, G. europaeus NBRC $3261 ; 12$, G. nataicola LMG $1536^{\mathrm{T}} ; 13$, G. xylinus JCM $7644^{\mathrm{T}}$; 14 , G. xylinus subsp. sucrofermentans JCM $9730^{\mathrm{T}}$; 15 , 'G. xylinus subsp. nonacetoxidans' JCM 10150. ND, Not determined.

\begin{tabular}{|c|c|c|c|c|c|c|c|c|c|c|c|c|c|c|c|c|c|}
\hline \multirow{2}{*}{$\begin{array}{l}\text { DNA-DNA } \\
\text { similarity group }\end{array}$} & \multirow[t]{2}{*}{ Strain no. } & \multirow[t]{2}{*}{$\mathrm{G}+\mathrm{C}$ content $(\mathrm{mol} \%)$} & \multicolumn{15}{|c|}{ Levels of DNA-DNA similarity with strain (probe) } \\
\hline & & & 1 & 2 & 3 & 4 & 5 & 6 & 7 & 8 & 9 & 10 & 11 & 12 & 13 & 14 & 15 \\
\hline \multirow[t]{3}{*}{ I } & NBRC $14820^{\mathrm{T}}$ & 59 & 100 & 9 & 6 & 5 & 8 & 4 & 6 & 9 & 10 & 18 & 5 & 11 & 12 & 15 & 20 \\
\hline & NBRC 14816 & 58 & 100 & 11 & 6 & 4 & & 3 & 7 & 10 & & & 6 & & & & \\
\hline & NBRC 14817 & 59 & 100 & 12 & 7 & 4 & & 3 & 8 & & & & 7 & & & & \\
\hline II & NBRC 14815 & 62 & 23 & 100 & 29 & 5 & 15 & & 18 & 22 & 17 & 37 & 22 & 26 & 15 & 21 & 30 \\
\hline \multirow[t]{2}{*}{ III } & LMG $1582^{\mathrm{T}}$ & 61 & & 21 & 100 & 83 & 30 & & 20 & 23 & 34 & 53 & 20 & 25 & 25 & 13 & 29 \\
\hline & LMG 1584 & 61 & 25 & & 88 & 100 & & & 11 & & & & & & & & \\
\hline \multirow[t]{5}{*}{ IV } & DSM $11826^{\mathrm{T}}$ & $60 \dagger$ & & 42 & 44 & & 100 & & & 77 & 50 & & 53 & 53 & 52 & 37 & 58 \\
\hline & NBRC 14822 & 61 & 8 & 26 & 14 & 9 & & 100 & 83 & 71 & & & 34 & 52 & & & \\
\hline & LMG 1688 & 61 & 12 & 34 & 13 & 10 & 68 & 100 & 100 & 75 & 45 & & 41 & 58 & 31 & 32 & 48 \\
\hline & LMG 1689 & 60 & 11 & 40 & 14 & 13 & & 100 & 94 & 71 & & & 49 & 59 & & & \\
\hline & DSM $11804^{\mathrm{T}}$ & $61^{*}$ & & & 40 & & 94 & 73 & & 100 & 59 & 60 & 47 & 51 & 42 & 32 & 66 \\
\hline \multirow[t]{3}{*}{ V } & DSM $6160^{\mathrm{T}}$ & $57 \ddagger$ & 15 & 30 & 23 & & 39 & & & 48 & 100 & & 70 & 56 & & & 24 \\
\hline & JK2 & ND & & & & & & & & & & 100 & & & & & \\
\hline & NBRC 3261 & 58 & 9 & 45 & 22 & 10 & 28 & 29 & 38 & 48 & 68 & 75 & 100 & 43 & 15 & 12 & 38 \\
\hline VI & LMG $1536^{\mathrm{T}}$ & 62 & 8 & 46 & 13 & 3 & 55 & 3 & 7 & 23 & 40 & & 37 & 100 & 29 & 31 & 59 \\
\hline \multirow[t]{3}{*}{ VII } & JCM $7644^{\mathrm{T}}$ & 62 & 12 & 45 & 38 & & 47 & & & 34 & 50 & & 47 & 42 & 100 & 67 & 98 \\
\hline & JCM $9730^{\mathrm{T}}$ & $62 \$$ & & 47 & 30 & & 33 & & & 42 & 46 & & 56 & 51 & 73 & 100 & 98 \\
\hline & JCM 10150 & $63 \|$ & & 13 & 10 & & 16 & & & 30 & 24 & & 16 & 16 & 69 & 69 & 100 \\
\hline G. liquefaciens & NBRC $12388^{\mathrm{T}}$ & 659 & & 9 & 7 & & 6 & & & 5 & 8 & & 5 & 6 & 8 & 5 & 14 \\
\hline A. aceti & NBRC $14818^{\mathrm{T}}$ & 589 & & 10 & 5 & & 8 & & & 8 & 9 & & 12 & 3 & 9 & 8 & 5 \\
\hline
\end{tabular}

*Boesch et al. (1998).

†Sokollek et al. (1998).

$\ddagger$ Sievers et al. (1992).

\$Toyosaki et al. (1995).

IIKojima et al. (1998).

SLisdiyanti et al. (2000).

et al., 2001; Lisdiyanti et al., 2002; Loganathan \& Nair, 2004; Yamada et al., 2000). Growth at 0, 1 and $5 \%$ acetic acid was determined by using AE broth (Entani et al., 1985) as a basal medium because G. europaeus and G. entanii strains require acetic acid for growth and these species exhibit a strong tolerance to acetic acid (Entani et al., 1985; Schüller et al., 2000; Sievers et al., 1992). Growth on ethanol was determined by using the medium described by Gosselé et al. (1983a) (Gosselé's medium). Utilization of ammoniacal nitrogen was determined by using Hoyer-Frateur medium (De Ley \& Frateur, 1974), Frateur's modified Hoyer's medium (De Ley et al., 1984) and the medium described by Asai et al. (1964) (Asai's medium). Ethanol, Dglucose or D-mannitol was used as sole carbon source for the media. Acid production from sugars and sugar alcohols was examined by using the medium described by Asai et al. (1964).

Cells of all strains studied were Gram-negative and rod-shaped, measured $0 \cdot 5-1 \cdot 0$ by $1 \cdot 0-3 \cdot 0 \mu \mathrm{m}$ and were non-motile. They were aerobic, catalase-positive and oxidase-negative. The strains did not produce a watersoluble brown pigment on the culture media used, oxidized acetate and lactate, produced acid from ethanol and grew well on mannitol agar and glutamate agar. They grew in the presence of $0.35 \%$ acetic acid in AG medium and grew without acetic acid, but not at 1 or $5 \%$ acetic acid, in $\mathrm{AE}$ broth. However, NBRC 3261 grew at $1 \%$ acetic acid and DSM $6160^{\mathrm{T}}$ and JK2 grew even at $5 \%$ acetic acid. Production of 5-keto-D-gluconate from D-glucose varied with the strain studied. G. hansenii strains produced acid from galactitol. G. saccharivorans produced acid from propan-1-ol. Data of other characteristics are shown in Table 3.

The terms 'production of acid from ethanol' and 'oxidation of ethanol' may bring about some confusion in the identification of acetic acid bacteria. Acid production from ethanol and oxidation of ethanol involve basically the same biochemical reaction by acetic acid bacteria, the production of acetic acid from ethanol. This has been tested 
Table 3. Phenotypic characteristics of Gluconacetobacter strains studied

Abbreviations: KGA, keto-D-gluconate; +, positive; -, negative; w, weak; vw, very weak; ND, not determined. Note: all strains were Gramnegative, rod-shaped bacteria, positive for catalase, production of acetic acid from ethanol, growth on mannitol agar and glutamate agar, growth at $0.35 \%$ acetic acid in AG medium, production of dihydroxyacetone, production of D-gluconate from D-glucose and production of acid from L-arabinose, D-ribose, D-xylose, D-galactose, D-glucose, ethanol, butan-1-ol and butan-2-ol. All strains are negative for production of a water-soluble brown pigment, oxidase, production of 2,5-diketo-D-gluconate from D-glucose and production of acid from L-sorbose, lactose and starch. Strains: 1, G. hansenii NBRC $14820^{\mathrm{T}}$; 2, G. hansenii NBRC 14817; 3, G. hansenii NBRC 14816; 4, Gluconacetobacter sp. NBRC 14815; 5, G. saccharivorans LMG $1582^{\mathrm{T}}$; 6, G. saccharivorans LMG 1584; 7, G. oboediens DSM 11826 ${ }^{\mathrm{T}}$; 8, G. oboediens NBRC 14822; 9, G. oboediens LMG 1688; 10, G. oboediens LMG 1689; 11, G. oboediens DSM 11804; 12, G. europaeus DSM 6160 ${ }^{\mathrm{T}}$; 13, G. europaeus JK2; 14, G. europaeus NBRC 3261; 15, G. nataicola LMG 1536 ${ }^{\mathrm{T}}$; 16, G. xylinus JCM 7644 ${ }^{\mathrm{T}}$; 17, G. xylinus JCM 9730; 18, G. xylinus JCM 10150.

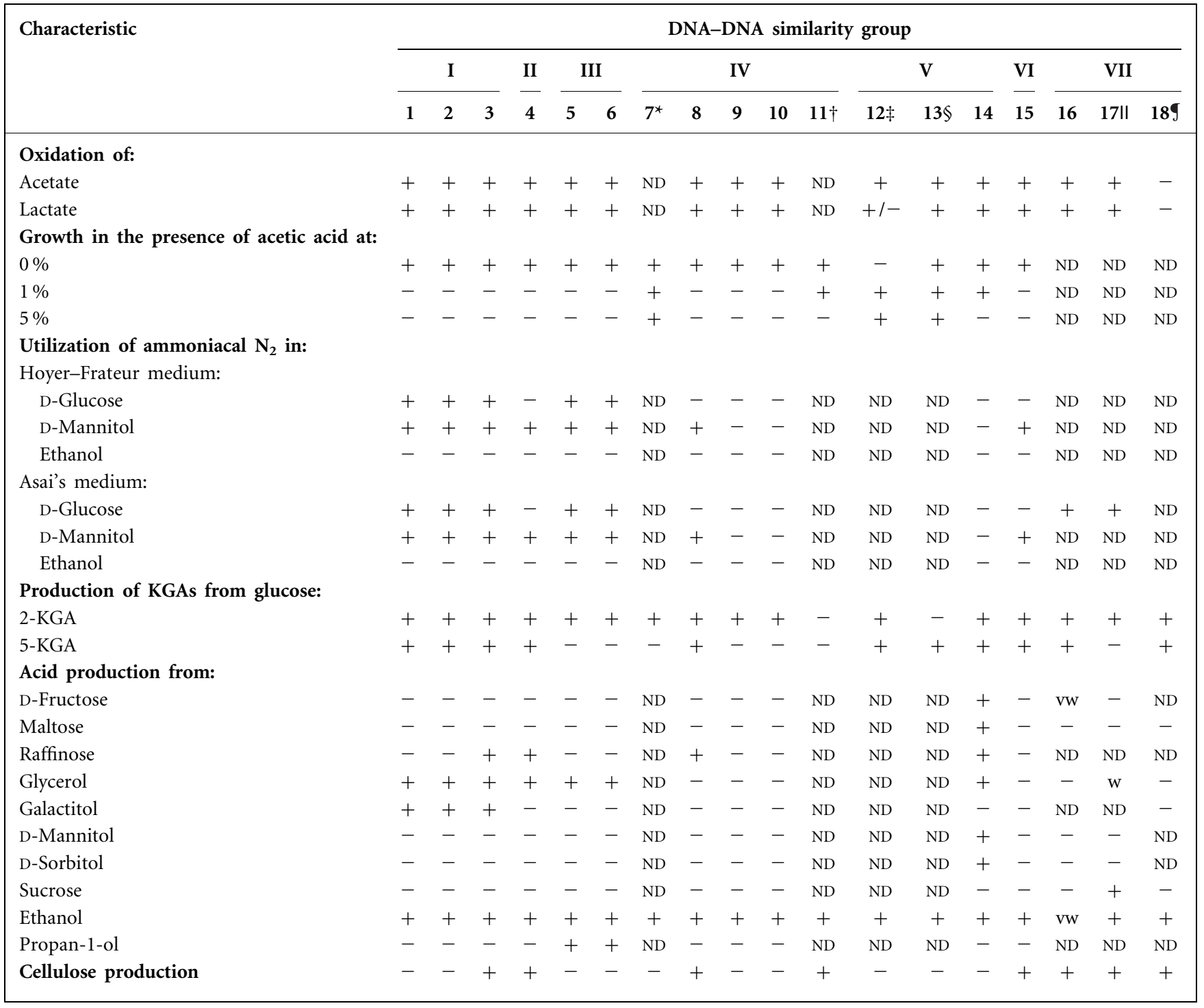

${ }^{\star}$ Sokollek et al. (1998).

$\dagger$ Boesch et al. (1998).

$\ddagger$ Sievers et al. (1992).

$\$$ Trček et al. (2000).

IIToyosaki et al. (1995).

SKojima et al. (1998). 
by the titration of acetic acid produced with $0 \cdot 1 \mathrm{M} \mathrm{KOH}$ (Asai et al., 1964), respirometry (Asai et al., 1964; Kondo \& Ameyama, 1958), the dissolution of $\mathrm{CaCO}_{3}$ around colonies (Asai et al., 1964; Shimwell et al., 1960; Swings et al., 1992) or the colour change of the indicator (Carr, 1968; Swings et al., 1992). Media used for the test usually contain yeast extract, peptone or other organic substances as nitrogen sources with ethanol. However, when small amounts of acetic acid are produced in liquid media and on solid media, the acid may be masked by diffusion into the media or the buffer action of the above nitrogenous substances and may give a false-negative result. Therefore, acid production from ethanol should be evaluated cautiously and recorded correctly for the identification of acetic acid bacteria. The dissolution of $\mathrm{CaCO}_{3}$ is appropriate for the production of acid from ethanol in the light of the history of acetic acid bacteria.

The strains studied did not grow on ethanol in Gosselé's broth. In contrast, a false growth was recognized on Gosselé's agar plates because the strains studied showed scant growth on agar plates with and without ethanol. The utilization (assimilation) of or growth on organic carbon compounds means the biochemical uptake of the compounds into cellular materials, and the increase in cellular mass has been regarded as the uptake of the compounds. The increase in turbidity in liquid cultures and in colonial mass on agar media has been used as a parameter for the utilization of organic compounds. However, the media used for the utilization of carbon compounds have not been specified and some media contain yeast extract, peptone or other organic substances as nitrogen sources and growth factors, such as Gosselé's agar medium. When the medium contains much larger amounts of yeast extract or peptone than of the carbon source, these organic, nitrogenous substances may serve as the carbon source as well and often give a false-positive result. Therefore, the results obtained should be examined carefully. Media containing agar cause much more difficulty in determination of growth (Cleenwerk et al., 2002; Gosselé et al., 1983a; Swings et al., 1992). When the bacteria examined require some growth factors, defined media would be preferable to complex media for the determination of utilization of carbon compounds. Acid production from sugars and sugar alcohols is often confusing with the utilization of the organic carbon compounds. This may cause false-positive growth because basal media usually contain considerable amounts of yeast extract, such as the medium reported by Asai et al. (1964).

The strains of G. hansenii and G. saccharivorans grew well at the expense of D-glucose and D-mannitol on Hoyer-Frateur medium, Frateur's modified Hoyer's medium and Asai's medium, but did not grow at the expense of ethanol. The utilization of ammoniacal nitrogen of acetic acid bacteria has been reported to vary with carbon compound used (Gosselé et al., 1983b; Navarro et al., 1999; Shimwell, 1957). Asaia strains grew well on Hoyer-Frateur medium with
D-glucose or D-mannitol as sole carbon source, but not with ethanol (Katsura et al., 2001; Lisdiyanti et al., 2000; Yamada et al., 2000; Yukphan et al., 2004). Frateuria aurantia strains are biochemically similar to acetic acid bacteria and they grow on Hoyer-Frateur medium and Frateur's modified Hoyer's medium with D-mannitol as sole carbon source, but not with ethanol or D-glucose (Lisdiyanti et al., 2003). In addition, the utilization of ammoniacal nitrogen on HoyerFrateur medium and Frateur's modified Hoyer's medium was recognized to be inappropriate for the identification of Acetobacter strains because some strains gave false-positive growth (Lisdiyanti et al., 2000). Therefore, the taxonomic value of the utilization of ammoniacal nitrogen is rather limited to some species or genera of acetic acid bacteria and should be examined by using several kinds of carbon compounds on defined media.

The production of cellulose varied with strains studied. Cellulose production was reported to be useful for the separation of acetic acid bacteria, particularly G. xylinus in the old descriptions of acetic acid bacteria (De Ley \& Frateur, 1974; Vaughn, 1957), but some strains of $G$. hansenii, G. oboediens, G. xylinus and G. nataicola and Gluconacetobacter sp. NBRC 14815 also produced cellulose in the present study. Therefore, the production of cellulose is not useful for the differentiation of the species in the genus Gluconacetobacter. Pellicles produced by acetic acid bacteria do not always mean real cellulose and the production of real cellulose should be confirmed by boiling the pellicles with a dilute $\mathrm{NaOH}$ solution (Forng et al., 1989; Navarro et al., 1999).

\section{Description of Gluconacetobacter saccharivorans sp. nov.}

Gluconacetobacter saccharivorans (sac.cha.ri.vo'rans. L. neut. n. saccharum sugar; L. part. adj. vorans devouring; N.L. masc. adj. saccharivorans sugar-devouring).

Cells are Gram-negative and rod-shaped, measure $0 \cdot 5-0 \cdot 8$ by $1 \cdot 0-1 \cdot 5 \mu \mathrm{m}$, occur singly or in pairs and are non-motile. Strictly aerobic, catalase-positive and oxidase-negative. Cellulose and a water-soluble brown pigment are not produced. Acetate and lactate are oxidized to $\mathrm{CO}_{2}$ and $\mathrm{H}_{2} \mathrm{O}$. Acetic acid is produced from ethanol. Growth occurs in the presence of $0.35 \%$ acetic acid in AG medium, but not at 1 or $5 \%$ acetic acid in AE broth. D-Glucose and D-mannitol are assimilated in Hoyer-Frateur medium, Frateur's modified Hoyer's medium and Asai's broth, but not ethanol. Dihydroxyacetone is produced from glycerol and growth occurs on mannitol agar and glutamate agar. D-Gluconate and 2-keto-D-gluconate are produced from D-glucose, but 5-keto-D-gluconate and 2,5-diketogluconate are not. Acid is produced from L-arabinose, D-ribose, D-xylose, D-galactose, D-glucose, glycerol, ethanol, propan-1-ol, butan-1-ol and butan-2-ol, but not from D-fructose, L-sorbose, lactose, maltose, sucrose, raffinose, galactitol, D-mannitol, Dsorbitol or starch. The major quinone is Q-10 and the minor quinone is Q-9. 
The type strain is LMG $1582^{\mathrm{T}}\left(=\mathrm{NRIC} 0614^{\mathrm{T}}\right.$ ) and its $\mathrm{G}+\mathrm{C}$ content is $61 \mathrm{~mol} \%$. Isolated from beet juice in Germany in 1927.

\section{Description of Gluconacetobacter nataicola sp. nov.}

Gluconacetobacter nataicola [na.ta.i'co.la. N.L. neut. n. nataum nata (a food composed of cellulose produced by acetic acid bacteria in South-East Asia); L. masc. suff. -cola inhabitant; N.L. masc. n. nataicola nata inhabitant, referring to the isolation source, nata de coco, of the type strain).

Cells are Gram-negative and rod-shaped, measure $0 \cdot 5-0 \cdot 8$ by $1 \cdot 0-1 \cdot 5 \mu \mathrm{m}$, occur singly or in pairs and are non-motile. Strictly aerobic, catalase-positive and oxidase-negative. Cellulose is produced, but water-soluble brown pigment is not. Acetate and lactate are oxidized to $\mathrm{CO}_{2}$ and $\mathrm{H}_{2} \mathrm{O}$. Acetic acid is produced from ethanol. Growth occurs in the presence of $0.35 \%$ acetic acid in AG medium, but not at 1 or $5 \%$ acetic acid in AE broth. D-Mannitol is assimilated in Hoyer-Frateur medium, Frateur's modified Hoyer's medium and Asai's broth, but not D-glucose or ethanol. Dihydroxyacetone is produced from glycerol and growth occurs on mannitol agar and glutamate agar. D-Gluconate, 2-keto-D-gluconate and 5-keto-D-gluconate are produced from D-glucose, but 2,5-diketogluconate is not. Acid is produced from L-arabinose, D-ribose, D-xylose, D-galactose, D-glucose, ethanol, butan-1-ol and butan-2-ol, but not from D-fructose, L-sorbose, lactose, maltose, sucrose, raffinose, glycerol, galactitol, D-mannitol, D-sorbitol, propan-1-ol or starch. The major quinone is $\mathrm{Q}-10$ and the minor quinone is Q-9.

The type strain is LMG $1536^{\mathrm{T}}\left(=\mathrm{NRIC} 0616^{\mathrm{T}}\right)$ and its $\mathrm{G}+\mathrm{C}$ content is $62 \mathrm{~mol} \%$. Isolated from nata de coco in the Philippines.

\section{Emended description of Gluconacetobacter hansenii (Gosselé et al. 1983) Yamada et al. 1998}

Cells are Gram-negative and rod-shaped, measure $0 \cdot 5-0 \cdot 8$ by $1 \cdot 0-1 \cdot 5 \mu \mathrm{m}$, occur singly or in pairs and are non-motile. Strictly aerobic, catalase-positive and oxidase-negative. Cellulose (with the exception of one strain) and a watersoluble brown pigment are not produced. Acetate and lactate are oxidized to $\mathrm{CO}_{2}$ and $\mathrm{H}_{2} \mathrm{O}$. Acetic acid is produced from ethanol. Growth occurs in the presence of $0.35 \%$ acetic acid in AG medium, but not at 1 or $5 \%$ acetic acid in AE broth. DMannitol and D-glucose are assimilated in Hoyer-Frateur medium, Frateur's modified Hoyer's medium and Asai's broth, but not ethanol. Dihydroxyacetone is produced from glycerol and growth occurs on mannitol agar and glutamate agar. D-Gluconate, 2-keto-D-gluconate and 5-keto-D-gluconate are produced from D-glucose, but not 2,5-diketogluconate. Acid is produced from L-arabinose, D-ribose, D-xylose, D-galactose, D-glucose, galactitol, ethanol, butan1-ol and butan-2-ol, but not from D-fructose, L-sorbose, lactose, maltose, sucrose, glycerol, D-mannitol, D-sorbitol, propan-1-ol or starch. The major quinone is Q-10 and the minor quinone is Q-9.

The type strain is NBRC $14820^{\mathrm{T}}\left(=\mathrm{LMG} 1527^{\mathrm{T}}=\mathrm{NCIB}\right.$ $\left.8745^{\mathrm{T}}\right)$ and its $\mathrm{G}+\mathrm{C}$ content is $62 \mathrm{~mol} \%$. Isolated from local vinegar in Jerusalem, Israel.

\section{Acknowledgements}

We thank Y. Yamada for his advice on Latin grammar. We also thank N. Tanaka and R. Suzuki for producing phylogenetic trees. This work was supported in part by a research grant (2004) of the Institute for Fermentation, Osaka, Japan.

\section{References}

Asai, T., lizuka, H. \& Komagata, K. (1964). The flagellation and taxonomy of genera Gluconobacter and Acetobacter with reference to the existence of intermediate strains. J Gen Appl Microbiol 10, 95-126.

Bernardo, E. B., Neilan, B. A. \& Couperwhite, I. (1998). Characterization, differentiation and identification of wild-type cellulose-synthesizing Acetobacter strains involved in nata de coco production. Syst Appl Microbiol 21, 599-608.

Boesch, C., Trček, J., Sievers, M. \& Teuber, M. (1998a). Acetobacter intermedius, sp. nov. Syst Appl Microbiol 21, 220-229.

Boesch, C., Trček, J., Sievers, M. \& Teuber, M. (1998b). Acetobacter intermedius sp. nov. In Validation of the Publication of New Names and New Combinations Previously Effectively Published Outside the IJSB, List no. 67. Int J Syst Bacteriol 48, 1085-1086.

Brosius, J., Dull, T. J., Sleeter, D. D. \& Noller, H. F. (1981). Gene organization and primary structure of a ribosomal RNA operon from Escherichia coli. J Mol Biol 148, 107-127.

Carr, J. G. (1968). Methods for identifying acetic acid bacteria. In Identification Methods for Microbiologists (Society for Applied Bacteriology Technical Series no. 2), part B, pp. 1-8. Edited by B. M. Gibbs \& D. A. Shapton. London: Academic Press.

Cleenwerck, I., Vandemeulebroecke, K., Janssens, D. \& Swings, J. (2002). Re-examination of the genus Acetobacter, with descriptions of Acetobacter cerevisiae sp. nov. and Acetobacter malorum sp. nov. Int J Syst Evol Microbiol 52, 1551-1558.

De Ley, J. \& Frateur, J. (1974). Genus Acetobacter Beijerinck 1898. In Bergey's Manual of Determinative Bacteriology, 8th edn, pp. 276-278. Edited by R. E. Buchanan \& N. E. Gibbons. Baltimore: Williams \& Wilkins.

De Ley, J., Swings, J. \& Gosselé, F. (1984). Genus Acetobacter Beijerinck 1898, 215 ${ }^{\mathrm{AL}}$. In Bergey's Manual of Systematic Bacteriology, vol. 1, pp. 268-274. Edited by N. R. Krieg \& J. G. Holt. Baltimore: Williams \& Wilkins.

Dellaglio, F., Cleenwerck, I., Felis, G. E., Engelbeen, K., Janssens, D. \& Marzotto, M. (2005). Descriptions of Gluconacetobacter swingsii sp. nov. and Gluconacetobacter rhaeticus sp. nov., isolated from Italian apple fruit. Int J Syst Evol Microbiol 55, 2365-2370.

Entani, E., Ohmori, S., Masai, H. \& Suzuki, K.-I. (1985). Acetobacter polyoxogenes sp. nov., a new species of an acetic acid bacterium useful for producing vinegar with high acidity. J Gen Appl Microbiol 31, 475-490.

Ezaki, T., Hashimoto, Y. \& Yabuuchi, E. (1989). Fluorometric deoxyribonucleic acid-deoxyribonucleic acid hybridization in microdilution wells as an alternative to membrane filter hybridization in 
which radioisotopes are used to determine genetic relatedness among bacterial strains. Int J Syst Bacteriol 39, 224-229.

Felsenstein, J. (1981). Evolutionary trees from DNA sequences: a maximum likelihood approach. J Mol Evol 17, 368-376.

Felsenstein, J. (1983). Parsimony in systematics: biological and statistical issues. Annu Rev Ecol Syst 14, 313-333.

Felsenstein, J. (1985). Confidence limits on phylogenies: an approach using the bootstrap. Evolution 39, 783-791.

Forng, E. R., Anderson, S. M. \& Cannon, R. E. (1989). Synthetic medium for Acetobacter xylinum that can be used for isolation of auxotrophic mutants and study of cellulose biosynthesis. Appl Environ Microbiol 55, 1317-1319.

Frateur, J. (1950). Essai sur la systématique des Acetobacters. Cellule 53, 285-392 (in French).

Gosselé, F., Swings, J., Kersters, K. \& De Ley, J. (1983a). Numerical analysis of phenotypic features and protein gel electropherograms of Gluconobacter Asai 1935 emend. mut. char. Asai, Iizuka, and Komagata 1964. Int J Syst Bacteriol 33, 65-81.

Gosselé, F., Swings, J., Kersters, K., Pauwels, P. \& De Ley, J. (1983b). Numerical analysis of phenotypic features and protein gel electrophoregrams of a wide variety of Acetobacter strains. Proposal for the improvement of the taxonomy of the genus Acetobacter Beijerinck 1898, 215. Syst Appl Microbiol 4, 338-368.

Jojima, Y., Mihara, Y., Suzuki, S., Yokozeki, K., Yamanaka, S. \& Fudou, R. (2004). Saccharibacter floricola gen. nov., sp. nov., a novel osmophilic acetic acid bacterium isolated from pollen. Int J Syst Evol Microbiol 54, 2263-2267.

Katsura, K., Kawasaki, H., Potacharoen, W., Saono, S., Seki, T., Yamada, Y., Uchimura, T. \& Komagata, K. (2001). Asaia siamensis sp. nov., an acetic acid bacterium in the $\alpha$-Proteobacteria. Int J Syst Evol Microbiol 51, 559-563.

Katsura, K., Yamada, Y., Uchimura, T. \& Komagata, K. (2002). Gluconobacter asaii Mason and Claus 1989 is a junior subjective synonym of Gluconobacter cerinus Yamada and Akita 1984. Int J Syst Evol Microbiol 52, 1635-1640.

Kimura, M. (1980). A simple method for estimating evolutionary rates of base substitutions through comparative studies of nucleotide sequences. J Mol Evol 16, 111-120.

Kojima, Y., Tonouchi, N., Tsuchida, T., Yoshinaga, F. \& Yamada, Y. (1998). The characterization of acetic acid bacteria efficiently producing bacterial cellulose from sucrose: the proposal of Acetobacter xylinus subsp. nonacetoxidans subsp. nov. Biosci Biotechnol Biochem 62, 185-187.

Komagata, K. \& Suzuki, K. (1987). Lipid and cell wall analysis in bacterial systematics. Methods Microbiol 19, 161-206.

Kondo, K. \& Ameyama, M. (1958). Carbohydrate metabolism by Acetobacter species. I. Oxidative activity for various carbohydrates. Bull Agric Chem Soc Jpn 22, 369-372.

Lisdiyanti, P., Kawasaki, H., Seki, T., Yamada, Y., Uchimura, T. \& Komagata, K. (2000). Systematic study of the genus Acetobacter with descriptions of Acetobacter indonesiensis sp. nov., Acetobacter tropicalis sp. nov., Acetobacter orleanensis (Henneberg 1906) comb. nov., Acetobacter lovaniensis (Frateur 1950) comb. nov., and Acetobacter estunensis (Carr 1963) comb. nov. J Gen Appl Microbiol 46, 147-165.

Lisdiyanti, P., Kawasaki, H., Widyastuti, Y., Saono, S., Seki, T., Yamada, Y., Uchimura, T. \& Komagata, K. (2002). Kozakia baliensis gen. nov., sp. nov., a novel acetic acid bacterium in the $\alpha$ Proteobacteria. Int J Syst Evol Microbiol 52, 813-818.

Lisdiyanti, P., Yamada, Y., Uchimura, T. \& Komagata, K. (2003). Identification of Frateuria aurantia strains isolated from Indonesian sources. Microbiol Cult Coll 19, 81-90.
Loganathan, P. \& Nair, S. (2004). Swaminathania salitolerans gen. nov., sp. nov., a salt-tolerant, nitrogen-fixing and phosphate-solubilizing bacterium from wild rice (Porteresia coarctata Tateoka). Int J Syst Evol Microbiol 54, 1185-1190.

Navarro, R. R. \& Komagata, K. (1999). Differentiation of Gluconacetobacter liquefaciens and Gluconacetobacter xylinus on the basis of DNA base composition, DNA relatedness, and oxidation products from glucose. J Gen Appl Microbiol 45, 7-15.

Navarro, R. R., Uchimura, T. \& Komagata, K. (1999). Taxonomic heterogeneity of strains comprising Gluconacetobacter hansenii. J Gen Appl Microbiol 45, 295-300.

Saito, H. \& Miura, K. (1963). Preparation of transforming deoxyribonucleic acid by phenol treatment. Biochim Biophys Acta 72, 619-629.

Saitou, N. \& Nei, M. (1987). The neighbor-joining method: a new method for reconstructing phylogenetic trees. Mol Biol Evol 4, 406-425.

Schüller, G., Hertel, C. \& Hammes, W. P. (2000). Gluconacetobacter entanii sp. nov., isolated from submerged high-acid industrial vinegar fermentations. Int J Syst Evol Microbiol 50, 2013-2020.

Shimwell, J. L. (1957). The true significance of Hoyer's medium in the differentiation of Acetobacter species. J Inst Brew 63, 44-45.

Shimwell, J. L., Carr, J. G. \& Rhodes, M. E. (1960). Differentiation of Acetomonas and Pseudomonas. J Gen Microbiol 23, 283-286.

Sievers, M., Sellmer, S. \& Teuber, M. (1992). Acetobacter europaeus sp. nov., a main component of industrial vinegar fermenters in central Europe. Syst Appl Microbiol 15, 368-392.

Sokollek, S. J., Hertel, C. \& Hammes, W. P. (1998). Description of Acetobacter oboediens sp. nov. and Acetobacter pomorum sp. nov., two new species isolated from industrial vinegar fermentations. Int J Syst Bacteriol 48, 935-940.

Sugawara, H., Tanaka, N. \& Miyazaki, S. (2003). An e-workbench for the study of microbial diversity: the system design and basic functions. Microbiol Cult Coll 19, 59-67.

Swings, J., Gillis, M. \& Kersters, K. (1992). Phenotypic identification of acetic acid bacteria. In Identification Methods in Applied and Environmental Microbiology (The Society for Applied Bacteriology Technical Series no. 29), pp. 103-110. Edited by R. G. Board, D. Jones \& F. A. Skinner. Oxford: Blackwell Scientific.

Tamaoka, J. \& Komagata, K. (1984). Determination of DNA base composition by reverse-phase high-performance liquid chromatography. FEMS Microbiol Lett 25, 125-128.

Tanaka, M., Murakami, S., Shinke, R. \& Aoki, K. (2000). Genetic characteristics of cellulose-forming acetic acid bacteria identified phenotypically as Gluconacetobacter xylinus. Biosci Biotechnol Biochem 64, 757-760.

Thompson, J. D., Gibson, T. J., Plewniak, F., Jeanmougin, F. \& Higgins, D. G. (1997). The CLUSTAL_X windows interface: flexible strategies for multiple sequence alignment aided by quality analysis tools. Nucleic Acids Res 25, 4876-4882.

Toyosaki, H., Kojima, Y., Tsuchida, T., Hoshino, K., Yamada, Y. \& Yoshinaga, F. (1995). The characterization of an acetic acid bacterium useful for producing bacterial cellulose in agitation cultures: the proposal of Acetobacter xylinum subsp. sucrofermentans subsp. nov. J Gen Appl Microbiol 41, 307-314.

Trček, J. (2002). Genotypic characteristics of Gluconacetobacter hansenii LMG 1582 suggest its reclassification to a new species. Zebu Biotechnol Fake Unit Ljubljana Kempt 79, 19-26.

Trček, J. \& Teuber, M. (2002). Genetic and restriction analysis of the 16S-23S rDNA internal transcribed spacer regions of the acetic acid bacteria. FEMS Microbiol Lett 208, 69-75.

Trček, J., Raspor, P. \& Teuber, M. (2000). Molecular identification of Acetobacter isolates from submerged vinegar production, sequence 
analysis of plasmid pJK2-1 and application in the development of a cloning vector. Appl Microbiol Biotechnol 53, 289-295.

Vaughn, R. E. (1957). Genus III Acetobacter Beijerinck 1898. In Bergey's Manual of Determinative Bacteriology, 7th edn, pp.183-189. Edited by R. S. Breed, E. G. D. Murray \& N. R. Smith. Baltimore: Williams \& Wilkins.

Yamada, Y., Aida, K. \& Uemura, T. (1969). Enzymatic studies on the oxidation of sugar and sugar alcohol. V. Ubiquinone of acetic acid bacteria and its relation to classification of Gluconobacter and Acetobacter, especially of the so-called intermediate strains. J Gen Appl Microbiol 15, 186-196.

Yamada, Y., Hoshino, K. \& Ishikawa, T. (1997). The phylogeny of acetic acid bacteria based on the partial sequences of $16 \mathrm{~S}$ ribosomal
RNA: the elevation of the subgenus Gluconoacetobacter to the generic level. Biosci Biotechnol Biochem 61, 1244-1251.

Yamada, Y., Hoshino, K. \& Ishikawa, T. (1998). Gluconacetobacter corrig. (Gluconoacetobacter [sic]). In Validation of the Publication of New Names and New Combinations Previously Effectively Published Outside the IJSB, List no. 64. Int J Syst Bacteriol 48, 327-328.

Yamada, Y., Katsura, K., Kawasaki, H., Widyastuti, Y., Saono, S., Seki, T., Uchimura, T. \& Komagata, K. (2000). Asaia bogorensis gen. nov., sp. nov., an unusual acetic acid bacterium in the $\alpha$ Proteobacteria. Int J Syst Evol Microbiol 50, 823-829.

Yukphan, P., Potacharoen, W., Tanasupawat, S., Tanticharoen, M. \& Yamada, Y. (2004). Asaia krungthepensis sp. nov., an acetic acid bacterium in the $\alpha$-Proteobacteria. Int J Syst Evol Microbiol 54, 313-316. 